\title{
India nel quattrocento: Fifteenth-Century Italian Travel Writings on India
}

\author{
Jitamanyu Das \\ Doctoral Candidate (JRF), Department of English, Jadavpur University, ORCID: oooo-ooo1- \\ 5845-8098, jitamanyudas@gmail.com,
}

\begin{abstract}
Fifteenth-century Italian travel narratives on India by Nicolò dei Conti and Gerolamo di Santo Stefano present a detailed account of the India they visited, following the narrative tradition of the Italian Marco Polo. These narratives of the Renaissance were published as descriptive authorial texts of travellers to the East. Their importance was due to the authors' detailed first-hand experiences of the societies and cultures that they encountered, as well as the various trade centres of the period. These narratives were utilised by merchants, explorers, and Jesuits for a variety of purposes. The narratives of Nicolò dei Conti and Gerolamo di Santo Stefano thus became indispensable tools that were later distorted through numerous translations to suit the politics of Orientalism for the emerging colonial enterprises.

In my paper, I have attempted a re-reading of the particular texts to identify how Italy saw India, while illustrating through their history of publication the transformation that these narratives underwent later in order to objectify India in the West through the lens of Orientalism in their manner of representation.
\end{abstract}

Keywords: India, Italian Travel Writing, Orientalism, Renaissance, Translation

The study of Western approaches towards India and the Indian Ocean Region has gone through a noteworthy shift in the last few decades. Scholars of "maritime Asia" and the history of interconnected trade and commerce between the East and the West have refocused on the naval trade routes and re-assessed their role in the influence of Asia on Europe (Alpers, 2014; Chaudhuri, 1985; Chaudhuri 1990; Clark 2006; Das Gupta \& Pearson, 1987; Das Gupta \& Das Gupta, 2013; Panikkar, 1954; Subrahmanyam, 1990; Wills, 1993).

This emergence led to a de-centring of the "recorded" history of approaches towards the East during the Renaissance and the resulting changes in Western cultures (Tucci, 1974). However, this postcolonial ethos of re-evaluation had largely remained restricted to the economic and historical studies of the region. Only recently, a renewed interest in trade literature published during the Renaissance as sources depicting the motive and methods in which individual and systematic approaches towards India was initiated and sustained has come up and has since developed into a major aspect of this epistemic subject (Brotton, 2002; Harris, 2015; Howard, 2000; Jardine \& Brotton, 200o; Mitter, 2013; Moxham, 2016; Subrahmanyam, 2011, 2017). Their works illustrate a clear link between economic factors and the germination of interest in the East that had "re-surfaced" and had become a major governing factor behind the Renaissance "age of exploration," with multiple attempts to reach and "discover" alternative routes to India. This in turn further extended the epistemic expansions through the narratives of the merchants "visiting" the East.

(c) AesthetixMS 2021. This Open Access article is published under a Creative Commons Attribution Non-Commercial 4.0 International License (http://creativecommons.org/licenses/by-nc/4.o/), which permits non-commercial re-use, distribution, and reproduction in any medium, provided the original work is properly cited. For citation use the DOI. For commercial re-use, please contact editor@rupkatha.com. 
This idea of exploration and its association with trade is illustrated quite clearly in a book published in Venice in 1543 titled Viaggi fatti da Vinetia alla Tana, in Persia, in India, et in Constantinopoli:

"The world today owes a great deal to the activity of merchants [...] for each day increases our knowledge of many places and lands, thanks to their travels. Although many of these places were familiar to our ancestors in past centuries, their names have become strange and unknown, almost completely new, to the ears of modern man [...]" (as quoted in Tucci, 1974, p. 49) ${ }^{1}$

These lines above successfully capture the essence of the importance that contemporary Italian cognoscenti gave during the Renaissance to explorations and trade relationships with the East. This also marks the initiation of "new" attempts to reach the East, to rediscover places that they had "lost" contact with. Professor Indrani Das of Visva-Bharati University, in her lectures on the cultural history and background of Europe, sees this desire to reach India as stemming from a heritage that primarily separates the approach of Italy towards India from that of the other European nations attempting to penetrate the Orient (personal communication, 2018). Yet, the Italian merchants' ventures in and explorations of India have often not been properly acknowledged in the history of the Indian Ocean Region, despite them being major contributors to maritime trade during the Renaissance and the foremost producers of travel narratives at the same time (Formichi, 1950; Tucci, 1974, 2005).

Professor Giuseppe Tucci, who had dedicated his entire life to studying the Italian relationships with India, categorises the travellers and their accounts according to their respective ventures, as "Merchants and Travellers" and as "Missionaries" (Tucci, 1974, p. VI). At the same time, there is an oversimplification of the nature of the contacts to better illustrate the different purposes and to draw attention to how distinct they historically appear from the other European contacts with India. It must be kept in mind that the complexity of Italian connections with India far exceeded the scope of the quoted publication.

For example, Tucci goes to great lengths to establish the artistic, trade, and other cultural links that existed between the Indian empires and the Roman Empire. These connections indicate a pre-existing relationship between the two geographically separate and culturally unique spaces. The Roman need for trade with the accepted culturally superior and mighty empires of India was conducted with a sense of respect, and these trade relations with India helped Rome gain material treasure and cultural artefacts of great value (Tucci, 1956). The cultural influence, however, was lost with the fall of the Roman Empire. The Renaissance revival of interest in the Orient rekindled the need to re-establish the lost connection with India, information about which continued to exist both in the cultural memory and through the trade relations existing via Arabs (Tucci, 1974, p. 49).

Although Tucci includes Marco Polo in the list of "Merchants and Travellers", his purposes of travelling to India were in fact manifold and continue to be studied. Leonardo Olschki (1957) presents us with a very detailed study of Marco Polo's work Il Milione and demonstrates the complexity of approaching Marco Polo as a simple merchant or a traveller. Olschki's narrative meticulously documents the details hidden in Marco Polo's writing. He divides his observations into various sections including diverse aspects of the civilisations and cultures that Marco Polo had encountered in Asia, Nature and its elements, the religions and politics of Asia, the regions and their geographies, the cultural and societal differences among the inhabitants, the history of Asia that Marco Polo recorded, and details of medicinal practices in his work.

It is, however, a recent view of Marco Polo's travel that gives us a completely different reason. Anna Contadini (1999, p. 7), in her seminal essay on the "artistic contacts" between the East and the West, mentions that the Polo family's visit to the court of the Great Khan in China was perhaps a deputation governed by political reasons in addition to its overt mercantile needs, to 
forge an anti-Islamic union with the Mongols. That this was done at the behest of the Papacy indicates the growing understanding and need to ally with pagan empires of the East against the awareness of a major expanding threat in the form of Islam in the Near East.

However, the result of Marco Polo's travel to the East and the publication of his travel narrative II Milione (circa 1300) subsequently after his return to Venice set a precedent and created an interest in the East in the Italian public consciousness, unexpectedly encouraging adventurous voyages for the sole purpose of exploration. His narrative has great value for being extremely detailed and in certain sections remarkably objective to the point where it almost seems like an anthropological study of foreign lands (Formichi, 1950, p. 83). The description of the societies, their religious practices, and topographical records continued to be emulated by later travellers (Tucci, 1974, p. 52). The narrative became so popular that it was rapidly translated into all the major European languages and included in many travel anthologies of the time, including Giovanni Battista Ramusio's famed Delle Navigationi et Viaggi (1550) and Simon Grynaeus' Novus Orbis (16 $6^{\text {th }}$ century) (Tucci, 1974, p. 53).

This categorical interest in the exploration of the East in general and India in particular also emerged due to the inclusion of the Orient as a positive space in the Renaissance creative arts, with grand descriptions of its riches and the presentation of its products as exclusive and exotic (I. Das, personal communication, 2018). By the fifteenth century, this interest had governed many "missions" to the East, along with the need to spread Christianity and explore trade routes simultaneously (Formichi, 1950, p. 82; Tucci, 1974, p. 50).

At this point, in the fifteenth century, two important voyages were undertaken to the Orient by Nicolò dei Conti and Gerolamo di Santo Stefano. ${ }^{2}$ Both of them visited India and wrote in considerable detail about their experiences in India (Formichi, 1950, p. 83). However, there are more similarities in their writing than just being mere descriptive narratives of unfamiliar territory.

Both these narratives are stylistically very similar to Marco Polo, as they attempt to provide objectivity to a personal travel narrative. Nicolò dei Conti's narrative is all the more striking in this regard, as it completely removes his self-persona as he recounts his travel and captures in vivid details the exceptional Asian customs and sights. However, this self-removal from the narrative might have been an unexpected result of it being narrated by Conti to Poggio Bracciolini, who recorded it in volume four of his Historia de varietate fortunae. Poggio Bracciolini's effort was meant to anthologise and deliver an authentic account of Asia and feed the interest of the common people. Thus, the removal of Conti's persona was necessitated in this regard, as was the neutrality with which the extreme details were narrated (Baumgärtner, 2017, p. 278). The title of the narrative included in Giovanni Battista Ramusio's Delle Navigationi et Viaggi (Venice, 1554) points towards this aspect of being extremely detailed-"India Divided into Three Parts, and which is the Richest and Most Civilized, and of its Customs, and of Other Noteworthy Things in Various Places" (Quoted in Tucci, 1974, p. 56). Although several scholars admit possible alterations of Conti's narrative by Poggio Bracciolini to suit his "flowery style", Conti's memoir was still the most accurate description of India till then, accumulating 25 years of his travel through India and South-East Asia (Tucci, 1974, p. 55). Sanjay Subrahmanyam (2018, p. 30) opines that Conti's work possibly only received a written form due to the "intervention of a humanist "co-author'," a fact that further emphasises the importance given to the experience Conti had gained in his travel to Asia.

Nevertheless, this resulted in the immediate and extreme popularity of Conti's narrative included in volume four of Poggio Bracciolini's work, so much so that it was often separately circulated and read (Baumgärtner, 2017, p. 278). Book four of Historia de varietate fortunae which contained Conti's narrative was in fact the first to be published and circulated widely, with prompt translations appearing in Portuguese and Spanish in 1502 and 1503 respectively from the Latin text of 1492 (Baumgärtner, 2017, p. 278). A vulgate Italian edition was also made by 1550 for 
inclusion in Giovanni Battista Ramusio's famous travel anthology (Baumgärtner, 2017, p. 278). Yet, it is very interesting to note Ramusio's comment about Conti's memoir being unavailable by his time in Italy, so that a Portuguese edition from Lisbon had to be obtained and translated back into Italian (Tucci, 1974, p. 56). Professor Tucci (1974, p. 56) further observes that the original translation in Portuguese had appeared at the order of the King of Portugal himself and had been a major source of authentic information about many prominent Indian cities and trade centres. One can hardly overlook the apparent connection between the appropriation of the narrative and the colonising enterprise that Portugal had already initiated in India.

In contrast, the narrative of Gerolamo di Santo Stefano in the form of a letter that he had sent from Lebanon on $1^{\text {st }}$ September 1499 is the only major source about his life and travels (Tucci, 1974, p. 57). Although much shorter than Conti's narrative, it contains considerable details of the city of Calicut, the coast of Coromandel, the island of Ceylon, and other islands and places. The primary focus on trade is quite discernible through the emphasis on the trade centres and their accessibility vis-à-vis their importance in contemporary maritime trade. This narrative also found its place in the anthology of Ramusio (Tucci, 1974, p. 57). Gerolamo di Santo Stefano's narrative is distinguished because of his factual inputs regarding the spaces and their customs, as well as his commentary on the practices of particular cities and how they were different from others. He also highlighted the religious differences between the "Mahumetani" and the different cults of Hindus in his narrative. Interestingly, the new Christians settled in most of the port cities are also mentioned. Gerolamo di Santo Stefano's narrative emphasises the harmony among cultures and contrasts the different societal norms to a large extent. However, a comparison often occurs or is deliberately undertaken with the Christian tradition, which Gerolamo di Santo Stefano most obviously places above the infidels' cultural systems.

It must be considered that unlike Nicolò dei Conti, very little is known to us about Gerolamo di Santo Stefano. A major departure from the English translation which solely mentions Gerolamo (Hieronimo) di Santo Stefano is that the Italian translation points towards the voyage being undertaken jointly by Girolamo Adorno and Gerolamo di Santo Stefano, with the narrative sharing their experiences of travelling together (Formichi, 1950, p. 83; Longhena, 1929, p. 215; Major, 1857, content page \& p. 1 of "The Journey of Hieronimo di Santo Stefano, a Genoese"). Also, unlike the narrative of Conti which had been narrated and recorded with ample details about its famous narrator reaching us through various archived documents, very little is known to us about the authors Gerolamo Adorno and Gerolamo di Santo Stefano from their travel narrative or even other secondary sources. We only come to know about Gerolamo Adorno from a letter written by Ramusio, while we know from a letter that Christopher Columbus had written to Nicolò Oderico that Gerolamo di Santo Stefano was perhaps on his way to work for the king of Spain (Longhena, 1929, p. 215; Columbus, 1823, p. 322-23 quoted in Longhena, 1929, p. 215). The narrative was also particularly important because of the extent of trade practices that were mentioned, as well as the routes through which trade took place. The commercial aspect of trade and the exclusive products according to the different places are listed within the travelogue (Longhena, 1929, p. 239).

For a long time, the similarities between the two narratives were the common space visited and described by the narrators, and the commonalities in their experience as they had travelled during the same century. Although the purpose of their travels was also very similar, the experience and what they have narrated could not have been any less similar. Their perceptions of the East are marked by a sense of wonder, but their approaches to understanding the culture and the space are very different. While Gerolamo di Santo Stefano's letter presents everything as an experience in a matter-of-fact way, perhaps restricted due to the form of his prose, Nicolò dei Conti's narrative via Poggio Bracciolini reaches us with constant attempts to explain rituals and incidents witnessed, often with close comparisons to Christian equivalents. The Humanist approach of Poggio 
5 | India nel quattrocento: Fifteenth-Century Italian Travel Writings on India

Bracciolini is being very descriptive regarding the different episodes, while also recording historical details and facts about the places visited and their people.

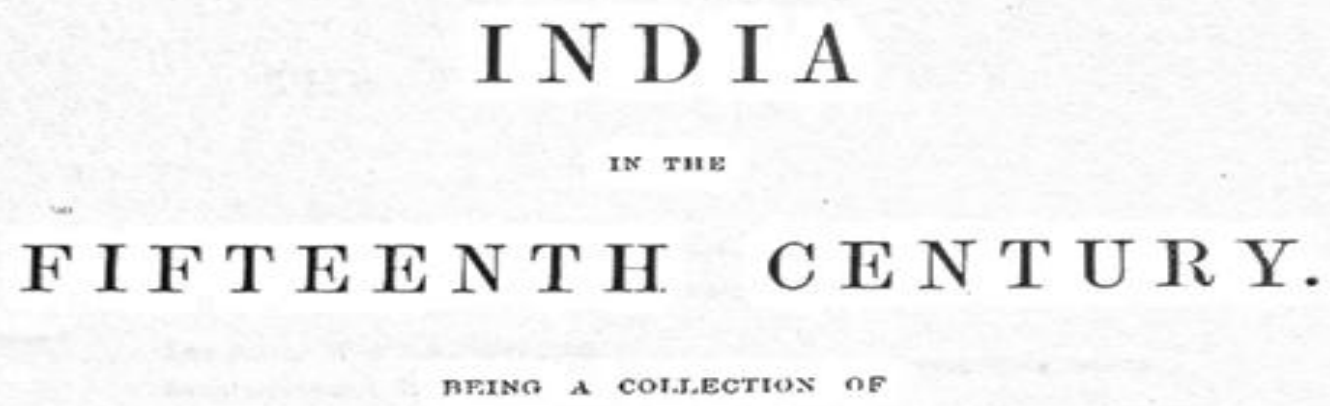

NARRATIVES OF VOYAGES

TO INDIA,

IN

THE CENTURY PRECEDING THE PORTUGUESE DISCOVERY

OF THE CAPE OF GOOD HOPE;

prosa

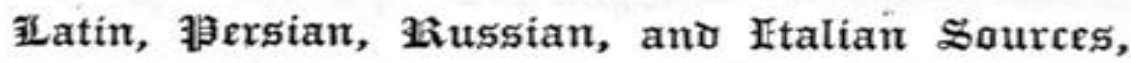

NOW First TRANSLATED INTO ENGLish.

EDITED, WITH AN INTRODUCTION,

BY

R. H. M A J O R, Es Q., F.S.A.

LON DON :

PRINTED FOR THE HAKLUYT SOCIETY.

a.DCCC.LvII.

Figure 1: Major, R.H. (ed.). (1857). India in the fifteenth century: Being a collection of narratives of voyages to India in the century preceding the Portuguese discovery of the Cape of Good Hope. London: Hakluyt Society.

The true extent of similarity, however, is not in the two narratives and their contents, but rather in the utilisation of the narratives in the colonial era. The "original" anthologising happened in Ramusio as a collection of exotic tales of "discovering unknown lands". It can be seen utilised within the Saidian framework as a mode of self-definition of the Occident, by highlighting the 
extreme differences that the Occident had with the Orient, arriving at the extreme usefulness of the "objective" accounts left by the travellers in this process (Das, 2020, p. 125).

The socio-cultural and religious differences between the two spaces were largely exaggerated in the translations as the purpose of the transmission of textual information itself underwent a massive change, from being travel memoirs to becoming guides of imperial endeavours, concurrently arriving at a method of knowledge generation on the East. ${ }^{3}$

Sanjay Subrahmanyam's (2018, p. 30) brilliant academic thoughts on the connection between the major trade centres of Early Modern Europe and Indian port cities and empires, and the gradual movement towards the establishment of colonial ventures in his book Empires Between Islam and Christianity 1500-1800 mentions the narrative of Conti along with the narratives of Afanasii Nikitin and "Abdur Razzaq Samarqandi", all three of which were interestingly included in the English collection India in the fifteenth century: Being a collection of narratives of voyages to India in the century preceding the Portuguese discovery of the Cape of Good Hope published by the Hakluyt Society (Major, 1857). Although Subrahmanyam (2018, p. 30) cites trade competition as the primary reason why these specific narratives lacked details on commercial interests, there is another dimension to this. The interest in stimulating descriptions of the East published from actual travel experiences gained precedence over the details of trade in their contemporary period, and most of the compositions took place keeping this in mind. Some narratives also had an ecclesiastical dimension to them, where the priority in publication became to point to the benevolence of God behind the safe return of the traveller (Major, 1857, p. 10 of "The Journey of Hieronimo di Santo Stefano, a Genoese"). ${ }^{4}$ Both of these points have to be kept in mind while approaching works of translation, as they are also a part of the politics of translation and dissemination of knowledge about the East.

The politics of translation into English also played a major role in this regard, with selective translation, a significant reduction, and the suggestive inclusion of notes into the narratives. This process often corrupted the originality of the narrative and its tone while maintaining the sanctity and the authority of the texts for the benefit of the translation and its acceptance.

The English translations of both Nicolò dei Conti and Gerolamo di Santo Stefano published by Hakluyt Society included together in India in the fifteenth century: Being a collection of narratives of voyages to India in the century preceding the Portuguese discovery of the Cape of Good Hope are reductive in nature as they significantly omit from the original narrative. Although it can be argued that these narratives only aim to focus on India and the experiences of the travellers there, the reduction is without any clarifications or notes by the translators to the texts. It can only be assumed by looking at the title of the publication. Furthermore, a subtle emphasis can be found in the way the translations carry a more critical attitude towards the Indian experience than the authors or narrators had. In this regard, the grouping of the four authors from different empires, none of which had an active colonial enterprise in India, is quite telling. The British utilisation of their narratives translated and published in 1857, the year of the first Indian armed revolt against the British rule, depends upon narratives which can be termed neutral and possessing no direct links with the British imperial agenda, yet can be made critical of the culture and religion of people shown as "infidels". Sections of the narrative that underlined the positives were muted, as were the descriptions of flora and fauna that were quite positive in their original manuscripts. Instead, the "Orient" was turned into a hostile space through the careful addition of notes within the narrative (Das, 2020, p. 130). Professor Tucci (1974, p. 56) quotes a line from the book to dispel this hostility that was sought to be included in the English translation of the narrative, as Conti's narrative describes the people that Conti met as: "They live very civilly and without cruelty of any kind, do not lead the inhuman life of barbarous peoples, and are gentle, benign and merciful." 
Interestingly, the "English" translations of the narratives of Nicolò dei Conti and Gerolamo di Santo Stefano appeared in 1857, just as the native discontent with the East India Company rule in India was starting to take a tangible shape and could no longer be kept hidden. The politics of translating these two narratives in a certain way, as evident from reading them today, along with other non-English narratives translated soon afterwards, reveals that there was a careful effort to portray India and its inhabitants in a way that would be beneficial for the Raj (Das, 2020, p. 123132).

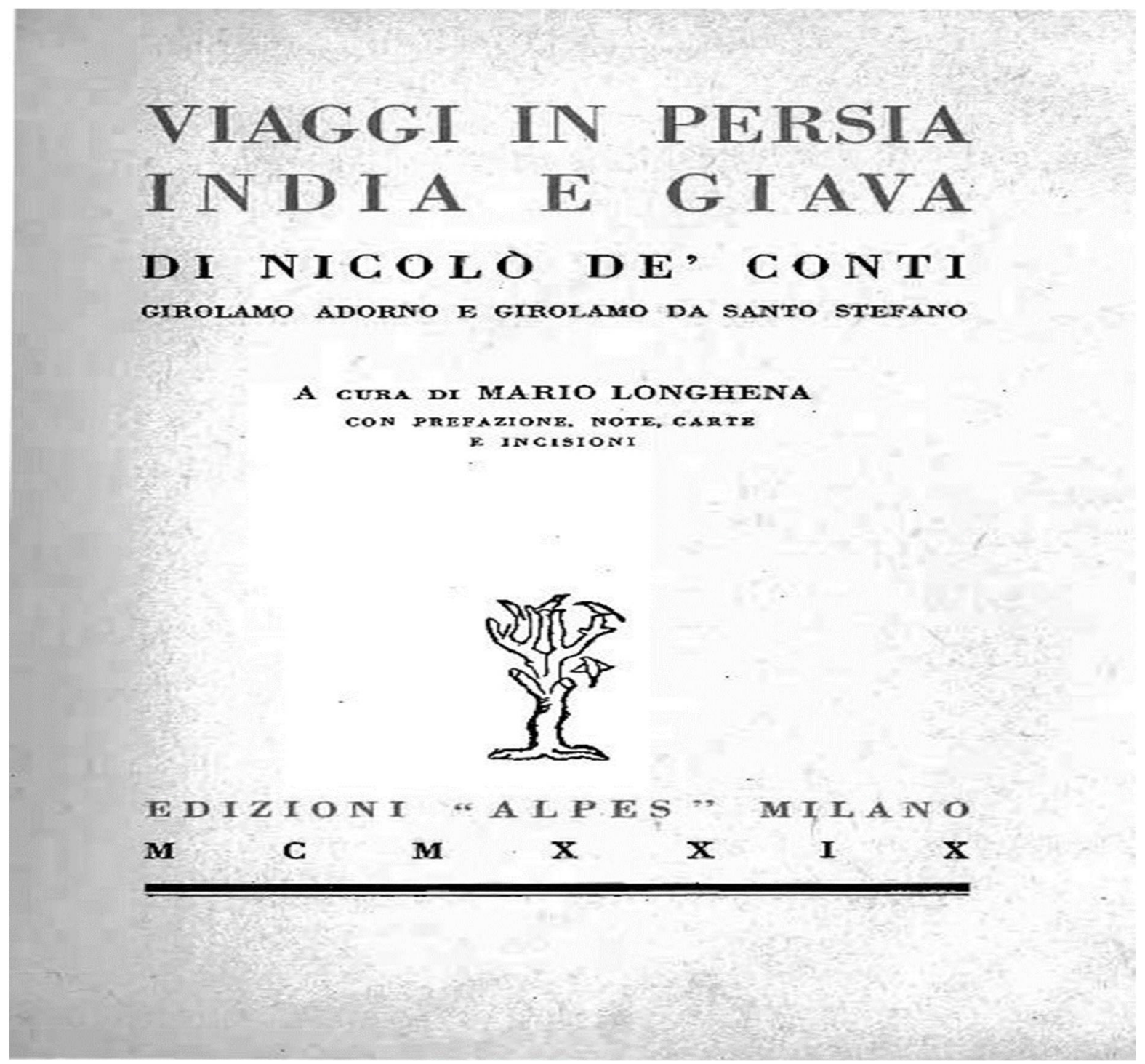

Figure 2: Longhena, Mario (ed.). (1929). Viaggi in Persia, India e Giava di Nicolò de' Conti, Girolamo Adorno e Girolamo da Santo Stefano. Milan: Alpes.

Mario Longhena's Italian edition of Viaggi in Persia, India e Giava di Nicolò de' Conti, Girolamo Adorno e Girolamo da Santo Stefano is also not completely free of the bias introduced and standardised by the British regarding the portrayal of India. The Italian narratives are almost free of the kind of tampering that can be seen in the English translations, and the notes included in the texts are also most certainly academic, with Longhena providing a detailed introduction as well as footnotes for the benefit of a modern reader. However, it must be noted that this particular 
publication also includes illustrations that were a part of the earlier translated manuscripts, and which inherently attempted to emphasise the extreme cultural differences and exaggerated incidents and events narrated in the book through the visual medium.

For any reader studying the texts, a side-by-side reading of the narratives of Nicolò dei Conti and Gerolamo di Santo Stefano from the 1857 English translation and Mario Longhena's 1929 Italian anthology would reveal the stark differences inherent in the length, the description, and the tone. Longhena's edition also makes the readers aware of the possible corruption in the written narratives, through Poggio Bracciolini in the former and the presence of Girolamo Adorno in the case of the latter. This is extremely relevant to form a neutral image of how the narratives were conceived, and to decipher the "real" experiences of the narrators. The change of tone becomes quite obvious when Longhena's (1929, p. 57) note quotes Nicolò dei Conti's journey to Asia written down by Poggio Bracciolini as "peregrinazioni attraverso l'Asia, condita di particolari curiosi ed interessanti", an arduous journey which captures or describes the curious and the interesting. It is very much possible that Poggio Bracciolini sensed that the journey of Nicolò dei Conti was a great event in itself, with the details of the voyage to the East unparalleled till then. The narrative of Gerolamo di Santo Stefano on the other hand, sent as a letter, confirms the surprise of the travellers through the narration itself as they tried to capture the marvellous experiences they had during their travel to the East.

Interestingly, unlike Subrahmanyam's view of Nicolò dei Conti's narrative lacking significant mercantile details, Longhena (1929, p. 83) creates a separate section in his introduction to the text of Conti consolidating the visited cities and ports, and their trade practices as well as the trade routes. This significant feature of Longhena's notes also points towards the academic importance given to re-tracing the journey as well as establishing the routes through which trade was undertaken. It also gives us an idea of the objects that were traded and their contemporary importance. Although less detailed than Conti's narrative in this regard, the narrative of Gerolamo di Santo Stefano has immense value due to its focus on the time taken to travel from one city to another, as well as the record of other traders and their movements. Gerolamo di Santo Stefano faithfully recorded the entire route which was used till the $19^{\text {th }}$ century for trade and travel to the East (Major, 1857, p. 3 of "The Journey of Hieronimo di Santo Stefano, a Genoese").

Thus, it is very evident that Europe's encounter with India in the fifteenth century contributed through the travellers' narratives to the corpus of Western knowledge about India and was put to use for a long time afterwards, with other Western nations' views being built on it.

A significant change in the European attitude towards Indian aesthetics derived out of the classical antiquities "re-discovered" from the time of the Roman Empire, as well as the contemporary visual representations and accompanying narrative explanations from first-hand experiences gained through the publication of the travel narratives across Europe. A noteworthy contribution to understanding this development can be found in Partha Mitter's critically acclaimed book Much Maligned Monsters: History of European Reactions to Indian Art (1977). Although he restricts himself primarily to the domain of the visual arts and how they underwent a change with the growing contacts between East and West, the resultant concepts he has presented in explaining the change of perception of the West towards the East aid us meaningfully in the study of such cultural connections. Mitter (2013, p. 2) explains the "stereotypical delineation" by the individual Western traveller as not a "deliberate conspiracy", but rather a result of "certain prejudices stemming from his Christian background as well as from a clash of tastes involving two very different traditions." He (2013, p. 5) reveals a very interesting phenomenon where, based on the written accounts, illustrations were produced to accompany the texts, first in illustrated manuscripts and, with the invention of printing, in printed versions of texts. He cites the example of Marco Polo's narrative which was illustrated by the Medieval artist Boucicaut Master, and in 
doing so the artist situated the exposition of European Medieval beliefs onto the travel experience. Lacking any direct exposure to the Eastern aesthetic and having only the written text to interpret, the artist depended on the Western artistic imagination and the Christian dogma of portraying paganism of all forms as originating from hell and essentially devilish in nature and appearance (Mitter, 2013, p. 5-7). While Boucicaut attempted to bring to the fore a theme containing the "sensational and exotic" of the East in his illustration to make the text more appealing, this altered the understanding of the narrative to a large extent as well. Subsequently, Mitter follows up this example with the problem of Christian ecclesiastical influence corrupting the narrative and descriptions. He highlights this through the example of Franciscan friar Odorico da Pordenone and his account of travel to India (Mitter, 2013, p. 11). It must be remembered that as a Franciscan friar, the intention of Odorico da Pordenone was noticeably unlike that of the merchants or explorers of his time. His representation of the pagan society and its cultures, much like many other missionaries and Jesuits who had travelled to the East, had to be distinctly pejorative.

Partha Mitter (2013, p. 34) is mostly silent about the narratives of Nicolò dei Conti and Gerolamo di Santo Stefano except for one brief mention of Conti. The "original" narratives of these two travellers were mostly positive in their description of India and were not much influenced by either the Christian tradition of representing the pagan as devil-worshippers or the Orientalist mindset of representing the East as hostile and its residents as 'uncivilised' or 'uncultured'.

Immediately following Nicolò dei Conti and Gerolamo di Santo Stefano, Ludovico di Varthema had arrived in India from 1503 and 1508. His travel narrative was published in Rome in 1510 as Itinerario de Ludouico de Varthema Bolognese. His travel accounts are significantly elaborate and offer details to Western readers about the East which were previously unknown. His narrative style was also significantly different from the tradition of Marco Polo and displays the tendency to critique religious practices quite often. Mitter quotes Varthema's description of "Indian gods" and elucidates on the European tradition that dictated the creation or interpretation of the deity and its portrayal in a diabolical manner. The immediate translation and publication of Varthema's narrative in German included artworks that were similarly stereotypical and, keeping close to the textual narrative, produced artwork that portrayed the space and its religion in a very negative manner (Mitter, 2013, p. 15-20). This also initiated a new tradition that pursued this attempt to portray the "Indian gods" and religion as essentially anti-Christian in a way very similar to how Islam was perceived by Europe. Later travellers inspired by this tradition contributed to furthering it through their narratives. Partha Mitter captures the intrinsic connection between the travellers and their published narratives resulting in the development of a tradition informing the views of people built over time.

Therefore, looking closely, we can understand that travel narratives have been for long translated and interpreted with notes, annotations, and illustrations to politicise the narrative. These very translations contributed significantly to the tradition of defining the East in general and India in particular through the lens of Orientalism. Whereas the "original" narratives had a very different attitude at times and narrated the experience of the traveller in a descriptive (albeit occasionally exaggerated) manner, they attempted to follow the narrative tradition set by Marco Polo and presented India as a space of extraordinary sights.

The fifteenth-century thus became the period when, through the publication of the narratives of Nicolò dei Conti and Gerolamo di Santo Stefano in Italy and their rapid translations and adaptations in other European states and their languages, direct first-hand knowledge about India was transmitted to the West in considerable detail and became the foundation for the myriad approaches and varying attitudes towards India in the West. It can certainly be argued that these narratives were appropriated by the project of Orientalism because the voice of Italian travellers, having no colonial designs for India, provided abundant opportunities to define India with the 
amount of knowledge that they imparted. Nonetheless, it is an imperative part of postcolonial studies to approach such narratives critically to subtract any intervention that might have become embedded within the narratives and subsequently accepted as standard. This also eliminates the homogenisation of the Occident as a whole and its collective approach as being singular in form and manner towards India and the Orient.

Only through such re-reading of texts produced outside the colonial definition of India can we have a complete picture of the India that really was, re-write the history from Asia's perspective while giving an agency to the Orient and its people that they certainly deserve, and be able to finally have an impartial perspective into the connection between East and West as it had existed in reality across centuries.

\section{End Notes}

${ }^{1}$ Professor Tucci mentioned this book as anonymous in his work. However, Royal Collection Trust attributes this work to Giosafat Barbaro and published by Antonio Manuzio (https://www.rct.uk/collection/1072764/viaggi-fatti-da-vinetia-alla-tana-in-persia-in-india-et-inconstantinopoli-et), while Dumbarton Oaks Research Institute of Harvard University mentions this as an anthology of travel memoirs published by Antonio Manuzio (via abebook.co.uk, https://www.doaks.org/resources/rare-books/viaggi-fatti-da-vinetia-alla-tana-in-persia-in-indiaet-in-costantinopoli \& https://nrs.harvard.edu/urn-3:DOAK.RESLIB:31081818)

${ }^{2}$ There are different variations of the spellings of Nicolò dei Conti and Gerolamo di Santo Stefano's names. I have followed the spellings used by Professor Tucci (1974), except in the names of publications and their quotes.

${ }^{3}$ For a better understanding of the way in which the system appropriated non-English travel writing specifically about India, one might read - Subrahmanyam, S. (2017). Europe's India: Words, People. Empires, 1500-1800. Harvard University Press.

4 This was a common motif in many of the Italian travel narratives about India and especially prominent in that of Ludovico di Varthema.

\section{Acknowledgement}

I would like to thank Dr Doyeeta Majumder, Assistant Professor, Department of English, Jadavpur University, and Professor Indrani Das, Professor of Italian, Visva-Bharati University, for their constant encouragement, help and support in my research. I sincerely appreciate the help of Miss Sulagna Chattopadhyay, Assistant Professor, Department of English, Loreto College, for painstakingly going through my paper and giving her much-appreciated suggestions for the manuscript. I would also like to thank the anonymous reviewers of Rupkatha Journal for their constructive comments.

\section{References}

Alpers, E. A. (2014). The Indian Ocean in World History. Oxford University Press.

Baumgärtner, I. (2017). "CONTI, NICCOLÒ DE' (c. 1395-1469): Italian Merchant and Traveler”, in J. Speake (ed.), Literature of Travel and Exploration: An Encyclopedia. Routledge.

Brotton, J. (2002). Renaissance Bazaar: From the Silk Road to Michelangelo. Oxford University Press.

Chaudhuri, K. N. (1985). Trade and Civilisation in the Indian Ocean: An Economic History from the Rise of Islam to 1750. Cambridge University Press. 
---. (1990). Asia before Europe: Economy and Civilisation of the Indian Ocean from the Rise of Islam to 1750. Cambridge University Press.

Clark, H. R. (2006). Maritime Diasporas in Asia before da Gama: An Introductory Commentary. Journal of the Economic and Social History of the Orient, 49(4), 385-394. Retrieved December 02, 2019, from http://www.jstor.org/stable/25165166

Columbus, C., \& Spotorno, G. B. (1823). Codice diplomatico Colombo-Americano, ossia, Raccolta di Documenti Originali e inediti, spettanti a Cristoforo Colombo alla scoperta ed al Governo dell'America. Dalla stamperia e fonderia Ponthenier.

Contadini, A. (1999). Artistic Contracts: Present Scholarship and Future Tasks. Islam and Italian Renaissance. The Warburg Institute.

Das, J. (2020). Italian Travel Narratives on India: Translation in the Politics of British Imperialism. Dibrugarh University Journal of English Studies. vol. 28, 123-132.

Das Gupta, A., \& Pearson, M. N. (Eds.). India and the Indian Ocean: 1500-180o. Oxford University Press, (1987).

Das Gupta, A., \& Das Gupta, U. (Ed.). (2013). Prabandha Samagra. Ananda Publishers. (Original work published 2001)

Formichi, C. (1950). CULTURAL RELATIONS BETWEEN ITALY AND INDIA: During the Middle Ages and the Renaissance. East and West, 1(2), 82-86. Retrieved September 18, 2018, from http://www.jstor.org/stable/29753464

Harris, J. G. (2015). The First Firangis: Remarkable Stories of Heroes, Healers, Charlatans, Courtesans E other Foreigners who Became Indian. Aleph Book Company.

Howard, D. (2000). Venice and the East: The Impact of Islamic World on Venetian Architecture, 1100-1500. Yale University Press.

Jardine, L., \& Brotton, J. (2000). Global Interests: Renaissance Art between East and West. Cornell University Press.

Longhena, M. (Ed.). (1929). Viaggi in Persia, India e Giava di Nicolò de' Conti, Girolamo Adorno e Girolamo da Santo Stefano. Alpes.

Major, R. H. (Ed.). (1857). India in the Fifteenth Century. Hakluyt Society.

Moxham, R. (2016). The Theft of India: The European Conquests of India, 1498-1765. HarperCollins Publishers India.

Mitter, P. (2013). Much Maligned Monsters: History of European Reactions to Indian Art. Oxford University Press. (Original work published 1977)

Olschki, L. (1957). L’Asia Di Marco Polo. Instituto per la collaborazione culturale.

Panikkar, K. M. (1954). Asia and Western Dominance: A Survey of the Vasco da Gama Epoch of Asian History, 1498-1945. George Allen \& Unwin.

Ramusio, G. B. (1554). Delle navigationi et viaggi. Appresso i Giunti.

Subrahmanyam, S. (Ed.). (1990). Merchants, Markets, And the State in Early Modern India. Oxford University Press.

---. (2011). Three Ways to be Alien: Travails and Encounters in the Early Modern World. Brandeis University Press.

---. (2017). Europe's India: Words, People. Empires, 1500-180o. Harvard University Press.

---. (2018). Empires Between Islam and Christianity 1500-180o. Permanent Black.

Tucci, G. (1956). Le Civiltà Dell' Oriente. vol. 1. Gherardo Casini Editore.

---. (1974). India and Italy. I.s.M.E.O.

---. (2005). Italia e Oriente. volume 1 of Il Nuovo Ramusio (F. D'Arelli, Ed.) ISIAO. 
Varthema, L. D. (1863). The Travels of Ludovico di Varthema in Egypt, Syria, Arabia Deserta and Arabia Felix, in Persia, India, and Ethiopia, A.D. 1503 to 1508 (J. W. Jones, Trans.). Hakluyt Society.

Varthema, L. D., \& Sardo, E. L. (Ed.) (2012). Itinerario de Ludovico de Varthema Bolognese. De Luca Editori d' Arte.

Wills, J. E., Jr. (1993). Maritime Asia, 1500-180o: The Interactive Emergence of European Domination. The American Historical Review, 98(1), 83-105. doi:10.2307/2166383

Jitamanyu Das is a doctoral candidate and Junior Research Fellow in the Department of English, Jadavpur University. His area of research is the Early Modern Italian writings on India. He is a former Project Fellow of the Centre of Advanced Study at the Department of English, Jadavpur University. He has previously worked as a trainer/faculty for the Initial Learning Program with Tata Consultancy Services. He did his Post Graduation in English Literature from Visva-Bharati University, Santiniketan. His areas of interest include the Early Modern Period, Italian fiction, Diaspora experience, Indian history and aesthetics, Japanese culture and literature, Post Modernity and Post Modern novels. 